\title{
E-LEARNING AND EFL TEACHERS' INTERCULTURAL COMPETENCE: AN ANALYSIS OF BENEFITS AND CHALLENGES
}

\author{
Url Jurnal: https://uia.e-journal.id/akademika/article/1323 \\ DOI : https://doi.org/10.34005/akademika.v10i01. 1323
}

Submitted: 2021-04-20

\section{Nurul Hasanah Fajaria}

As-Syafi'iyah Islamic University of Indonesia

nurulhasanah1139@gmail.com
Reviewed: 2021-05-10

Published: 2021-05-30

\author{
Tryanti R. Abdulrahman \\ As-Syafi'iyah Islamic University \\ of Indonesia \\ tryanti.abdulrahman@gmail.com
}

\begin{abstract}
This proposed research is aimed to find out to what extent can an online course in intercultural communication influence English language teachers' intercultural competence and their perception of intercultural communication hence aid in the development of intercultural awareness in an expanding circle university setting. This study is a first step to hold to find out teachers' intercultural competence after they took online course on language and culture or intercultural communication and explore their perspectives. This study used qualitative method using interview to gain the result. There are three lecturers who are participants of this study. Findings revealed various factors and effect of the online cultural training in developing teachers' intercultural communicative competence. Several similarities and differences of the participants' perception and critical evaluation of e-learning and intercultural competence were also found in this study. The advanced development of e-learning platform enables participants to learn many things, share cultural values, having and strengthen their intercultural competence as well as expanding their network for professional development. This study provides benefits and challenges faced by participants during the training. The most common problem they face is internet connection.
\end{abstract}

Keywords: E-Learning; English; lecturers; intercultural competence

\begin{abstract}
Abstrak: Penelitian yang diusulkan ini bertujuan untuk mengetahui sejauh mana kursus online dalam komunikasi antar budaya dapat mempengaruhi kompetensi antar budaya guru bahasa Inggris dan persepsi mereka tentang komunikasi antar budaya sehingga membantu dalam pengembangan kesadaran antar budaya dalam lingkungan universitas yang meluas. Studi ini merupakan langkah awal yang harus dilakukan untuk mengetahui kompetensi antar budaya guru setelah mereka mengikuti kursus online tentang bahasa dan budaya atau komunikasi antar budaya dan menggali perspektif mereka. Penelitian ini menggunakan metode kualitatif dengan menggunakan wawancara untuk memperoleh hasil. Ada tiga orang dosen yang menjadi peserta penelitian ini. Temuan mengungkapkan berbagai faktor dan pengaruh pelatihan budaya online dalam mengembangkan kompetensi komunikatif antar budaya guru. Beberapa persamaan dan perbedaan persepsi peserta dan evaluasi kritis terhadap e-learning dan kompetensi antar budaya juga ditemukan dalam penelitian ini. Pengembangan platform e-learning yang canggih memungkinkan peserta untuk mempelajari banyak hal, berbagi nilai budaya, memiliki dan memperkuat kompetensi antar budaya serta memperluas jaringan untuk pengembangan profesional. Kajian ini memberikan manfaat dan tantangan yang dihadapi peserta selama pelatihan. Masalah paling umum yang mereka hadapi adalah koneksi internet.
\end{abstract}

197 | Akademika | Vol 10 | No. 1 | 2021 
Kata kunci: E-Learning; Inggris; dosen pengajar; kompetensi antar budaya

\section{INTRODUCTION}

The emerging trend of EFL (English as a Foreign Language) education in recent years is a movement from a focus on language components such as vocabulary and grammar to a focus on the development of intercultural communicative competence such as the ability to communicate in the target language in real-life situations. The most objective of language learning is not characterized immovably in terms of the securing of communicative competence in an outside dialect and presenting an intercultural viewpoint into the EFL setting has gotten to be imperative. Furthermore, there is a growing awareness of the importance of intercultural competence must be owned by teachers especially EFL teachers (Davis et al, 2005; Gobel and Helmke, 2010; Sercu, 2006). As proposed by Byram (1997), intercultural competence not only requires the development of language proficiency as stated in communicative competence but also emphasizes an equally important ability of intercultural understanding, interpreting, and mediating.

In line with the phenomenon above, Indonesians are now competing with citizens of other countries in ASEAN Community, ASEAN Free Trade Area, and even globally in which everyone is demanded to use English as an intermediary language among countries that have different cultures. As an international language, English has a vital role to open the relation with global community. To confront the situation above, English teachers need to increase students' language skills, cultural awareness and intercultural competence (Sun, 2013; Tan, 2016; Wiseman \& Koster, 1993). In Indonesia as the setting of this study, English is used as a lingua franca in which it needs more liquid ideas of dialect and culture that must be adopted (Kachru, 2005; Crystal, 2008; Pennycook, 2007; Baker, $2009 \mathrm{~b})$. On the other hand, the function of English as an international lingua franca has gone past the conventional 'native speaker' English nations and has led to an essential require for a more intercultural approach to ELT that recognize this role for English.

Along with the initial need of intercultural and language competence, the utilization of technology especially internet has becoming an alternative way to bring cultural dimension along with English language complexity into EFL classroom. Numerous studies have been provided arguments concerning the potential use of technology to assist the method of dialect learning especially through advertising wide ranging resources to students as well as increasing the opportunity for people to interact (Chapelle, 2009; Ferdig, et.al, 2018). Additionally, Laurillard (2002) points out that the role of technology and E-learning have become integral parts of teaching and learning in technologies and e-learning's part as necessarily past of instructing and learning in higher instruction settings. $E$ learning offers a lot of advantages such as new pedagogic opportunities, 
convenience, better access to learning, affordability of materials and interaction with other people from other countries in a global marketplace.

In ELT settings, technology connects students across countries, provides new exciting learning environment, helps develop global citizenship and offers a professional enriching experience for teachers. While conventional study overseas and exchange programs aid to develop intercultural sensitivity and critical thinking, E-Learning in various forms such as Massive Open Online Course (MOOC), E-teacher development, Globally Networked Learning Environments (GNLE) and many more are powerful way to connect classroom around the world (Blessinger and Koybasyuk, 2012; Baker, 2018).

Even though E-learning has grown in eminence, it is far from "normalized" part of education process (Baker, 2012, Chambers and Bax, 2006; Chapelle, 2009). Likewise, the importance of cultural dimensions in ELT has also gained significance. In reality, a number of well-known applications have included the concept of tele-collaboration, pair learning in which understudies totally different places and societies interatomic through web utilizing apparatuses such as synchronous chat, mail, dialog gathering, and social or instruction organizing locales to back social interaction, talk, exchange, talk about and intercultural trade (Belx, 2003; Thorne, 2006; O'Dowd, 2007). Further, Fahmiyah (2019) found that there is a significant effect of learning media and students' linguistic intelligence.

There has been a remarkable amount of globally funded collaborations between those who use technology to accomplish certain goals; and most of the research only focuses on how is the application of technology in education settings and on the improvement of intercultural competence through locks in intercultural communication However, study on the utilization of e-learning instruct approximately the connection between dialect and culture and the forms of intercultural communication such as developing linguistic and intercultural awareness are never exists. Other scholarly works have to a lesser extent investigated the possibilities of e-learning for such teaching (for instance Furstenburg et al, 2001; Rogerson-Revell, 2003, Liaw, 2006) with generally positive results. Despite the fact that this is a relatively under explored area and there are no studies explicitly examining the teaching of a course focused on intercultural communication. Particularly in Indonesian EFL settings, no research examines the education of teacher on intercultural competence and their experiences. Laurillard (2002) and Chapelle (2009) have emphasized the require for more basic and subjective considers of innovation in dialect learning which go past improvement and bargain in a substantive way with the learners' encounters and course assessment. Importantly, we cannot disregard that societies and social orders will find ways to utilize innovations in any case of how unused and energizing they are. Hence, this insight has led to focus this research project on: first, elearning utilization to instruct the relationship between dialect and culture and the forms of intercultural communication such as to create 
etymological and intercultural mindfulness and second is reflection which specifically exploring teacher's perception after taking E-learning relates to the benefits and challenges perceived by them.

These two emphases of this research project: e-learning and intercultural communication and its reflection can be formalized through the following research question as follows:

First, to what extent can an online course in intercultural communication influence English language teachers' intercultural competence and second, what are teachers' perception toward online intercultural training?

This proposed research is aimed to find out to what extent can an online course in intercultural communication influence English language teachers' intercultural competence and their discernment of intercultural communication consequently within the improvement of intercultural mindfulness in an extending circle college setting. This study is a first step to hold to find out teachers' intercultural competence after they took online course on language and culture or intercultural communication and explore their perspectives. This study is expected to contribute later on foreign language education to enhance teachers and student's intercultural competence particularly through E-learning which will be helpful to language education and their cultivation of all-rounded quality.

\section{E-Learning}

E-learning stands for Electronic Learning that refer to an educational system or concept that utilizes information technology in a teaching and learning process. E-Learning is learning frame that's organized with the point of utilizing an electronic framework or computer so that it is able to back a learning prepare. According to Chandrawati (2010) E-learning is a distance learning process by combining the principles in the learning process with technology. In the same notion, Ardiansyah (2013) claims that E-learning is a learning system in which learning carried out without face-to-face meeting directly between educators and students. This means in conducting e-learning not only devices is needed but also capable teacher is important to run E-learning. Further, Kristiyani and Budiningsih (2018) mentioned that students who are taught using e-learning have higher interest to learn than who haven't.

Rosenberg (2001) points out the characteristics of E-learning are networked, which makes it able to quickly repair, retrieve or store, distribute, and also share information for learning. Furthermore, the characteristics of E-learning have been suggested by Nursalam (2008) include:

1. Using self-learning materials which are then stored on a computer, so that they can be accessed by students anytime and anywhere.

2. Utilizing a learning plan, educational programs, learning advance comes about, and things related to an instructive organization can be seen on each computer.

3. Utilizing an electronic technology service. 
4. Take advantage of a computer (digital media as well as computer networks) (P.135)

With those characteristics above, E-learning offer many benefits both for students and teachers. Pranoto,et all (2009) mentioned some benefits of E-learning are as follows: increase an active participation of students, improve a student's independent learning ability, improve a quality of teaching materials as well as training, and increasing the ability to be able to display information with information technology devices, which with ordinary devices will be difficult.

Moreover, E-learning also has some advantages such as provides flexibility, interactivity, speed, and visualization through the various advantages of each medium (Sujana, 2005, P. 253). In line with it, Tjokro (2009, Pg. 187) argues that E-learning has many advantages in terms of the easiness of absorbing the information in which the use of multimedia offer sophisticated form of images, text, animation, sound and video. Also, e-learning is relatively cost-effective, meaning that there is no need for instructors, no need for a minimum audience, and can be conducted anywhere. In addition to its benefits, e-learning also more concise, means that it does not contain much class formality, directly into a subject, subjects that suit student's needs.

Despite the benefits, e-learning also requires more additional equipment such as computers, monitors, keyboards, and so on (Gavrilova , 2006. Pg 354). Another shortcoming of E-learning described by Nursalam (2008, Pg. 40) are as mention below:

1. Lack of an interaction between students and teachers and even among students themselves.

2. Ignore academic and social aspects

3. Lead to training rather than education itself.

4. The change of teacher's role, from mastering conventional teaching technique to finding out learning technique using ICT.

5. Need to internet-savvy human assets.

6 . Need of authority in computer dialects.

7. Not all places have internet connection

8. Students are frustrated if they cannot access graphics, images, and videos due to inadequate equipment (software and hardware)

The aspects above demand the availability of an infrastructure that must be fulfilled. Such information varies in quality as well as accuracy so teacher's competence is required.

\section{Intercultural Competence}

Before discussing more about intercultural competence, it is important to understand the word culture as a basic notion that relates to intercultural competence. There are many definitions of cultures that have been declared by some experts particularly in an increasingly global world. Moran (2001) defines culture as "the great achievement of people as reflected in their history, social institutions, and works of art, architecture, 
music and literature" (p. 4), while Valdes (as cited in Baker, 2003) state that "every language lesson is about something and that something is cultural." Trinovitch (1980) explains culture as follows:

An all-inclusive framework which joins the natural and specialized behavior of human creatures with their verbal and nonverbal frameworks of expressive behavior beginning from birth, and this "all-inclusive system" is obtained as the local culture. This prepare which can be alluded to as "socialization", plans the person for the phonetically and non-linguistically acknowledged designs of the society in which he lives. (p. 550)

Synthesizing the abovementioned definitions, it can be concluded that culture is a system and a context that rule a group of people to think, feel, behave, and connect one to another. Culture is shared and learned by individuals within the same gather and can be exchange and adjected by another bunch of individuals. In connection to EFL, it can be suggested that when learning English, an understudy participates to a few degrees within the culture of the local speakers of the dialect being learned.

UNESCO (2013) defines intercultural competence as "having adequate relevant knowledge about particular cultures, as well as general knowledge about the sorts of issues arising when members of different cultures interact, holding receptive attitudes that encourage establishing and maintaining contact with diverse others, as well as having the skills required to draw upon both knowledge and attitudes when interacting with others from different cultures" (p.16). Byram (cited in Holmes, 2009) emphasizes that one way to divide intercultural competences into separate skills is to distinguish between knowledge of the culture, skills of interpreting/relating, skills of discovery/interaction, attitudes of curiosity/openness, and critical cultural awareness. Moreover, Byram and Morgan (1994) state that those who understand more than one social identity and national culture and who are capable of engaging in interaction with people from various cultural contexts are called intercultural speakers. From these definitions, it can be inferred that intercultural competence is the ability to communicate successfully with people of other group or culture. This ability involves emotional competence and cultural sensitivity as basic skills that need to be obtained or developed.

Recently, EFL has seen a growing frequency of references to the cultural dimension. There has been a development in the purposes and emphases of EFL, from linguistic and communicative competence to intercultural competence. As proposed by Byram (1997), intercultural competence not only requires the development of language proficiency as stated in communicative competence but also emphasizes an equally important ability of intercultural understanding, interpreting, and mediating. Corbett (2003) argues that teaching intercultural competence is intended to equip students with the strategies to observe and make sense of the target culture and help them acquire cultural skills which allow them to 
view different cultures from a perspective of informed understanding in order to achieve effective and appropriate intercultural communication.

It is believed that language teachers should be adequately familiar with the cultures associated with the foreign language they teach and the connections they have with these cultures. Numerous researchers suggest that teachers' intercultural competence is vital to teach a demographically changing population of students particularly in foreign language classroom. For example, Gobel and Helmke (2010) in a study of the importance of teachers' intercultural experience and the usefulness of precise instructional directives found that more highly intercultural experienced teachers are more likely to include cultural awareness, cultural meaning, understanding and intercultural issue into classrooms activity. Teachers' intercultural experience can encourage teachers to make more intense intercultural contacts with their students.

According to Byram (2008), the components of intercultural competence are information, abilities, and states of mind, supplemented by values that are portion of one's different social characters. The show of intercultural competence comprises of: 1) demeanors and values, which shape the establishment of intercultural competence, 2) information which implies not basically the information of specific objective culture but or maybe subjective culture which gives the coordinate knowledge into the worldview, working, prepare and hones of distinction social bunches and intercultural interaction, and 3) abilities of translating and relating or the capacity to translate occasions from another culture to clarify and relate them to occasions from one culture, abilities of revelation and interaction.

\section{Teacher's Intercultural Competence}

Moreover, along with the development of intercultural competence, foreign language education also becomes an urgent need for today's society. As the area of intercultural competence and foreign language teaching are related, schools, teachers, and learning environments are no longer sufficient only to educate students with subject matter but to also reflect and consider the cultures and diversities of the communities they serve. In today's foreign language classrooms, teachers attempt to incorporate a new perspective for learning which include multicultural issues and intercultural dimensions with language skills. Recently, English language teaching has seen a growing frequency of reference to the cultural dimension, in line with the cultural turn in other parts of the social life. Generally speaking, there has been a development in the purposes and emphases of language teaching, from linguistic competence to communicative competence, and then nowadays to intercultural competence. The development from linguistic to sociolinguistic to intercultural competence can be seen in theories of what the purposes and methods should be, as divergent to what they currently are.

Integrating culture in the language classroom through teaching English can be assumed as vital and compulsory. Hence, this insight has 
led foreign language research to develop an interest in cultural awareness and intercultural competence. However, there is no study focuses on the present situation of teachers' intercultural competence and culture and language teaching integration in their classroom. The previous study by Abdulrahman, T., Usu, NR., and Tanipu, Z (2016) shown that EFL teachers were willing to support the language and cultural objectives, but they had conflicts when having to prioritize language teaching or cultural teaching. Another study presented various teaching strategies to teach culture such as: culture capsule, culture clusters, culture assimilation, mini drama, cultoons, media, celebrating festival, and kinesics (Lutfiyyah \& Fajaria, 2011). This study is a first step to hold to find out teachers' perspective on understanding culture and EFL Education. Additionally, this will contribute later on foreign language education especially $E F L$ to enhance teachers and student's intercultural competence which will be helpful to language education and their cultivation of all-rounded quality. The idea of teaching culture is nothing new to EFL teachers. Cultural elements have practically been included even from the early phase of EFL teaching. Despite that fact, since this integration of culture is one of the most recent issues in the field of language teaching, a number of areas need to be investigated in order to further develop our understanding of culture in EFL education. One area that needs to be dealt with is related to teachers' perceptions of the importance of culture learning in various EFL programs and contexts.

\section{METHOD}

According to the topic characteristics and due to recent pandemic situation, qualitative method will be employed to explore a research problem (Creswell, 2007). In this study survey questionnaire in a form of open-ended follow-up interviews was conducted to collect qualitative data. Quantitative data were collected from three university EFL teachers and analyzed using data coding. The qualitative data were gathered from interviews to develop an in-depth understanding of the issues.

The meet questions are outlines as open questions to permit the members investigate their considerations and viewpoints based on their subjective encounters. The interview has been conducted in casual inviting circumstances by means of WA video call permitting members to donate honest and legitimate reactions.

The meet comes about are analyzed through consistent comparison approach (Glaser \& Strauss, 1967). The transcripts of met are examined, rehash, and compared in arrange to recognize the repeating subjects that risen from the participants' reactions to the questions. These repeating subjects are at that point inspected to decide their association to the investigate questions. The profile of the participants is presented in table 1. 
Table 1. Profile Of The Participants

\begin{tabular}{|c|c|c|c|c|}
\hline $\begin{array}{c}\text { Gender, } \\
\text { Age }\end{array}$ & Affiliation & $\begin{array}{l}\text { Teaching } \\
\text { experience }\end{array}$ & Teaching course & $\begin{array}{c}\text { Online course } \\
\text { experience }\end{array}$ \\
\hline Male, 31 & $\begin{array}{l}\text { IAIN } \\
\text { Salatiga }\end{array}$ & 6 years & $\begin{array}{l}\text { Computer Assisted } \\
\text { Language Learner } \\
\text { (CALL), Speaking, } \\
\text { Method } \\
\text { Language } \\
\text { Teaching } \\
\text { Reading }\end{array}$ & $\begin{array}{l}\text { MOOC } \\
\text { (Massive Open } \\
\text { Online Course) } \\
\text { as participant } \\
\text { and instructor } \\
\text { Intercultural } \\
\text { Course }\end{array}$ \\
\hline $\begin{array}{l}\text { Female, } \\
43\end{array}$ & $\begin{array}{l}\text { State } \\
\text { University } \\
\text { of } \\
\text { Gorontalo }\end{array}$ & 20 years & $\begin{array}{lr}\text { Writing, } & \text { TEFL, } \\
\text { General } & \text { English } \\
\text { Intensive Course }\end{array}$ & $\begin{array}{lr}\text { Online course } & \text { craining } \\
\text { tran } & \text { on } \\
\text { intercultural } & \\
\text { topic } & \text { and } \\
\text { multiple } & \\
\text { intelligence } & \end{array}$ \\
\hline $\begin{array}{l}\text { Female, } \\
40\end{array}$ & $\begin{array}{l}\text { Gorontalo } \\
\text { State } \\
\text { University }\end{array}$ & 15 years & $\begin{array}{l}\text { CCU, } \\
\text { Writing }\end{array}$ & $\begin{array}{l}\text { Online course in } \\
\text { integrated } \\
\text { culture and } \\
\text { technology in } \\
\text { teaching } \\
\text { English } \\
\text { Online } \\
\text { workshops on } \\
\text { learning media } \\
\text { and gender } \\
\text { topics }\end{array}$ \\
\hline
\end{tabular}

The three participants are purposefully selected because they are more accessible to the researchers. They are all university EFL teachers who involve in teaching activity in every semester. These teachers are between 30 to 45 years of age and they have between 5 and 20 years of teaching experience. Data will be collected by means of questionnaire (both using google form or paper), designed to profile Indonesian university EFL teachers' current professional self-concept, and specifically their point of views regarding the integration of culture and language teaching in English education and intercultural online course. Then, the purpose of interviews is to gather very personal information about teachers' lives and experiences for finding some possible sources of their perspective. Following are some attempts to ensure this study is credible and produce believable outcome. To anticipate the language barrier, survey and interview session were delivered by using Indonesian or English (depend on the participants' preference). Also, listening carefully to participants and restate the questions if they do not understand were useful strategies. The interview session was undertaken via WA video call, 
recorded, analyzed and the result were interpreted independently by researchers.

\section{RESULTS}

We present our findings in terms of how teachers see themselves (identity), their perspective on intercultural competence and e-learning including benefits and drawbacks and what they are trying to achieve as teachers (critical reflection). To provide the details of findings, the sections divided into three based on the participants: the first participant, the second participant, and the third participant.

\section{The first participant}

The first participant is a male English Teacher at English education Department at IAIN Salatiga. He is 31-year-old and has experience 6 years teaching. His teaching subjects include Computer assisted language learner (CALL), Speaking, Methods of language teaching and Reading. During his teaching career, he joined Indonesian Massive Open Online Course (MOOC) in 2007 and 2018 and American MOOC in 2010, 2019,2020 both as participant and instructor. Among these courses, he has taken two intercultural course that made him has great experiences in the area.

When he asked about the benefit of online courses, he mentioned that online courses can familiarize him the online learning in terms of its ematerials, modulation, operation, and so on inspiring him about good ideas of how to conduct his own online classes. Moreover, e-learning also taught him about the good roles of being an e-teacher. It is interesting that this participant mentioned there is no drawbacks of online courses. He perceived the intercultural competence is the basic provision one should have when mingling and interacting with people from different cultural background in both face to face and online/distance learning. This implies that teacher who study through training or formal education topic both online or face to face classroom must learn and have intercultural competence.

The first participant perceived also that he is competent enough but still need to be more competent. In this case, he thinks that it is important So far, he admitted that he always maintains good interaction with his friends who come from different background virtually. Furthermore, he identifies that interculturally competent teachers is one who can see differences in students as the way it is look for opportunities and solution instead of focusing on the problems those intercultural have created.

When he asked about how can knowledge of other people's cultures develop the learners' intercultural communicative competence as well as awareness of their own culture, he stated that because knowing is a good foundation for understanding, it is necessary to know first in order to understand thinks. The summary of his view can be seen in table 2 . 
Table 2. The $1^{\text {st }}$ Participant Perception

\begin{tabular}{|c|c|c|c|c|}
\hline $\begin{array}{l}\text { Benefits of e- } \\
\text { learning }\end{array}$ & $\begin{array}{l}\text { Drawbacks } \\
\text { of e-learning }\end{array}$ & $\begin{array}{c}\text { The } \\
\text { importance } \\
\text { of having } \\
\text { intercultural } \\
\text { competence }\end{array}$ & $\begin{array}{c}\text { Self- } \\
\text { perception }\end{array}$ & $\begin{array}{c}\text { Relation } \\
\text { between } \\
\text { cultural } \\
\text { knowledge } \\
\text { and } \\
\text { awareness }\end{array}$ \\
\hline $\begin{array}{l}\text { Familiar with } \\
\text { e-materials, } \\
\text { modulation, } \\
\text { operation, } \\
\text { how to } \\
\text { conduct own } \\
\text { online } \\
\text { classes and } \\
\text { good roles of } \\
\text { being an e- } \\
\text { teacher. }\end{array}$ & $\begin{array}{l}\text { No drawbacks } \\
\text { of online } \\
\text { course }\end{array}$ & $\begin{array}{l}\text { As a basic } \\
\text { provision } \\
\text { when mingling } \\
\text { and } \\
\text { interacting } \\
\text { with people } \\
\text { from different } \\
\text { cultural } \\
\text { background }\end{array}$ & $\begin{array}{l}\text { Competent } \\
\text { enough but } \\
\text { still need to } \\
\text { be more } \\
\text { competent. }\end{array}$ & $\begin{array}{l}\text { Knowing is a } \\
\text { good } \\
\text { foundation for } \\
\text { understanding }\end{array}$ \\
\hline
\end{tabular}

\section{Second participant}

Our second participant is a Female English teacher with the age of 43 and has 20 years teaching experience. She teaches at English Department, State University of Gorontalo. She teaches full time for Writing, TEFL (Teaching English as Foreign Language), General English Intensive Course. She has taken online course training on intercultural topic and multiple intelligences. In her opinion, taking online course benefits her in time management and flexibility. However, it is quite difficult to manage students' interaction especially in large class. The most common problem she faced is internet connection. She insists that teacher must have intercultural communicative competence in order to avoid the misunderstanding in teaching and learning process. She considers herself is interculturally competent and all teacher must have this competence in teaching their students as well as become of intercultural role model. She shared her experience in teaching that she has to prepare what kind of methods, strategies or approaches that she is going to use in class based on the students' character and cultural background. She identifies an interculturally competence teacher are those who can accept all the differences in class because of different culture. In addition to it, teacher must be able to handle the conflict happened in the classroom because of culture and make sure students can work cooperatively in team.

When she asked about how can knowledge of other people's cultures develop the learners' intercultural communicative competence as well as awareness of their own culture, she explained that by understanding others cultures they can improve their communication competence. Students learn other culture and also language includes nonverbal language such as gestures that may different in the culture, the 
intonation (the conflict could happen because of the different intonation meaning between Javanese and Sulawesi People). Because of this student can easily communicate with others from different cultural background and the conflict can be avoided. The summary of her view can be seen in table 3 .

Table 3. The $2^{\text {nd }}$ Participant Perception

\begin{tabular}{|c|c|c|c|c|}
\hline $\begin{array}{l}\text { Benefits of } \\
\text { e-learning }\end{array}$ & $\begin{array}{c}\text { Drawbacks } \\
\text { of e- } \\
\text { learning }\end{array}$ & $\begin{array}{c}\text { The importance } \\
\text { of having } \\
\text { intercultural } \\
\text { competence }\end{array}$ & $\begin{array}{c}\text { Self- } \\
\text { perception }\end{array}$ & $\begin{array}{c}\text { Relation } \\
\text { between } \\
\text { cultural } \\
\text { knowledge } \\
\text { and } \\
\text { awareness }\end{array}$ \\
\hline $\begin{array}{l}\text { Time } \\
\text { managemen } \\
\text { t and } \\
\text { flexibility. }\end{array}$ & $\begin{array}{l}\text { Difficult to } \\
\text { manage } \\
\text { students' } \\
\text { interaction } \\
\text { and } \\
\text { Internet } \\
\text { connection }\end{array}$ & $\begin{array}{l}\text { To avoid the } \\
\text { misunderstanding } \\
\text { in teaching and } \\
\text { learning process. }\end{array}$ & $\begin{array}{l}\text { Interculturally } \\
\text { competent. }\end{array}$ & $\begin{array}{l}\text { Understanding } \\
\text { other culture } \\
\text { can improve } \\
\text { communication } \\
\text { competence. }\end{array}$ \\
\hline
\end{tabular}

\section{Third participant}

The third participant is 40 years female English teacher who has 15 years teaching experiences. She holds a master degree and teach Bachelor degree in English Education Department at Gorontalo State University. She teaches skills and content courses including Cross Cultural Understanding (CCU), Drama, and Writing. She joined online courses in integrated culture and technology in teaching English for three months and some of online workshops on learning media and gender topics.

She argues that she learned a lot about tools and platform that she can use for online teaching. However, the internet connection is her main problem in taking or conducting online classes. She thinks that it is important to understand culture and have intercultural competence because it will help teacher in teaching diverse students who comes from different background. She considers that she is interculturally competent because she is quite tolerable and open minded. She like diversity and enjoy her teaching especially when it comes to CCU subject. She emphasizes that when we understand other culture it will help us to communicate and to interact smoothly with them as they will also able to understand ours. The summary of her view can be seen in table 4 .

Table 4. The $3^{\text {rd }}$ Participant Perception

\begin{tabular}{|c|c|c|c|c|}
\hline $\begin{array}{l}\text { Benefits of } \\
\text { e-learning }\end{array}$ & $\begin{array}{c}\text { Drawbacks } \\
\text { of e- } \\
\text { learning }\end{array}$ & $\begin{array}{c}\text { The importance } \\
\text { of having } \\
\text { intercultural } \\
\text { competence }\end{array}$ & $\begin{array}{c}\text { Self- } \\
\text { perception }\end{array}$ & $\begin{array}{c}\text { Relation } \\
\text { between } \\
\text { cultural } \\
\text { knowledge } \\
\text { and } \\
\text { awareness }\end{array}$ \\
\hline $\begin{array}{l}\text { learned a } \\
\text { lot about }\end{array}$ & $\begin{array}{l}\text { Internet } \\
\text { connection }\end{array}$ & $\begin{array}{l}\text { it will help teacher } \\
\text { in teaching }\end{array}$ & $\begin{array}{l}\text { interculturally } \\
\text { competent }\end{array}$ & $\begin{array}{l}\text { understand } \\
\text { other culture, }\end{array}$ \\
\hline
\end{tabular}




\begin{tabular}{lll} 
tools and & diverse students & will help us to \\
platform & who comes from & communicate \\
that can be & different & smoothly \\
used for & background. & \\
online & & \\
teaching & & \\
\hline
\end{tabular}

\section{DISCUSSION}

The discussion divided into two sections to follow the research questions. First, the influence of online course to the teachers' intercultural competence, the present findings are quite similar to Hendra (2019) and Jasmine (2021). We assume that the similarity is mainly influenced by the participants' age. All participants in these three studies are known as the millennial generation who are commonly identified by their ability to adapt toward the rapid change of technology. As Krashen (2012) stated, the millennial generation are digital natives and they growth together with the massive and the high level of technology.

Second, the perception of the teachers toward online intercultural training, the present findings are quite similar to Gobel and Helmke (2010). We assume that the similarity is mainly influenced by their experienced of joining online course related to intercultural topic. As Morgan (1994) said that those who understand more than one social identity and who are capable of engaging in interaction with people from various culture context are called intercultural speakers.

Based on the interview, participants reported various motivations of why they communicate with other friends on online class. Firstly, when traditional face to face interaction cannot be made up due to various reasons especially during pandemic, the online class is the best solution to do it. Second, even though their interaction is happened virtually but the cultural value they bring to interact with other are stay the same. This cannot be denied because some online platforms provide chat, discussion group, call, video call to interact directly.

\section{CONCLUSION}

The result revealed various factors and effect of the online cultural training in developing teachers' intercultural communicative competence. Several similarities and differences of the participants' perception and critical evaluation of e-learning and intercultural competence were also found in this study. In this study, the discussion attempts to explore participants' (who are English teachers) perspective toward the e-learning and intercultural competence. The advanced development of e-learning platform enables participants to learn many things, share cultural values, having and strengthen their intercultural competence as well as expanding their network for professional development. This study provides benefits 
and challenges faced by participants during the training. The most common problem they face is internet connection. 


\section{REFERENCES}

Abdulrahman, T., Usu, N. R., Tanipu, Z. (2016). Teachers' Perspectives on the Integration of Culture and EFL. Journal of ELT Research: The Academic Journal of Studies in English Language Teaching and Learning, 1 (2), 180-193. Retrieved from https://journal.uhamka.ac.id.index.php/jer/article/view/58

Brown, H. D.(1994). Principles of language learning and teaching. The USA: Prentice Hall Regents

Baker, W. (2008). A critical examination of ELT in Thailand: the role of cultural awareness. RELC, 39(1), 131-146.

Baker, W. (2009a). Intercultural awareness and intercultural communication through English: an investigation of Thai English language users in higher education. Unpublished Doctorate, University of Southampton, Southampton.

Baker, W. (2009b). The cultures of English as a lingua franca. TESOL Quarterly, 43(4), 567-592.

Baker, W. (2012). From cultural awareness to intercultural awareness: culture in ELT. ELT Journal, 66(1), 62-70

Byram, M. (1997). Teaching and assessing intercultural communicative competence. Clevedon, UK: Multilingual Matters.

Byram, M., Gribkova, B., \& Starkey, H. (2002). Developing the intercultural dimension in language teaching: A Practical Introduction for Teachers. Strasbourg: Council of Europe.

Byram, M. (2008). From foreign language education to education for intercultural citizenship: Essays and reflections. Clevedon: Multilingual Matters.

Çelik, S. (2005). ). Get your face out of mine: Culture-oriented distance in EFL Context: A helpful guide for Turkish EFL teachers. TÖMER Language Journal, 128, 37-50.

Corbett, J. (2003). An intercultural approach to English language teaching. Clevedon, England: Multiligual Matters

Creswell, J.W. (2007). Qualitative inquiry and research design: Choosing among !ve approaches (2nd ed.). Thousand Oaks, CA : Sage.

Fahmiyah M., \&naK. (2018) The Effect of Using Blogger Based Learning Media and Linguistics Intelligence on Indonesian Learning Outcomes. Akademika: Jurnal Teknologi Pendidikan, 7(2), 24-45. Retrieved from https://uia.e-journal.id/akademika/article/view/314

Gobel, K., \& Helmke, A. (2010). Intercultural learning in English as foreign language instruction:The importance of teachers' intercultural experience and the. Teaching and Teacher Education 26(8), 15711582.

Holmes, P. (2009). Intercultural competence: Asia-Pacific Region: Concepts, methods, and tools for intercultural competence and mediation. Report for the State of the Arts and Perspectives on Intercultural Competences and Skills, UNESCO. 
Kristiyani, Eva \& Budiningsih, Iffah. (2019). The Effect of e-learning Learning Strategy and Study Interest on Accounting Learning Outcomes. 8(1), Akademika: Jurnal Teknologi Pendidikan. Retrieved from https://uia.e-journal.id/akademika/article/view/341

Liaw, M. (2006). E-learning and the development of intercultural competence. Language learning and technology, 10(3), 49 -64. Retrieved from http://lt.msu.edu/vol10num3/liaw/default.html

Lokkesmoe, K. Kuchinke, P \& Ardichvili A. (2016) Developing crosscultural awareness through foreign immersion programs Implications of university study abroad research for global competency development, European Journal of Training and Development, 40 (3), Emerald insight, 155-170, https://doi.org/10.1108/EJTD-07-2014-0048 155-169

Lutfiyyah, Roghibatul \& Fajaria, NH. (2011). Impelementing Cultural Strategies in EFL Classroom. Edited Book of Best Practices in the Teaching of English. State University of Malang Press. Retrieved from https://www.academia.edu/45186339//mplementing Cultural Strategie $\underline{s}$ in EFL Classroom

Miles, M., and Huberman, M. (1994). Qualitative Data Analysis. London: Sage.

O'Dowd, R. (2007a). Evaluating the outcomes of online intercultural exchanges. ELT Journal, 61(2), $144-152$.

O'Dowd, R. (2007b). Online intercultural exchange: an introduction for foreign language teachers. Clevedon: Multilingual Matters.

Pennycook, A. (2007). Global Englishes and transcultural flows. London: Routledge.

Sercu, L. (2006). The foreign language and intercultural competence teacher: the acquisition of a new professional identity. Intercultural Education, 17(1), 55-72.

Sun, W. (2013). How to cultivate intercultural communication competence of non-English major students. Theory and Practice in Language Studies, 3(12), 2245-2249.

Tan, X. (2016). Language norm in various stages of English learning in mainland. Journal of Studies in Social Sciences, 14(1), 92-103.

Zhou, Y. (2011). A study of Chinese university EFL teachers and their intercultural competence. 